Ege Journal of Medicine / Ege Tıp Dergisi 2021; 60 (3): 259-268

\title{
Gender differences in applicability of guidelines in clinical practice of heart
} failure patients

\author{
Kalp yetersizliği olan hastalarda klinik pratikte kılavuzların uygulanabilirliğinde \\ cinsiyet farkı
}

\author{
Elton Soydan (D) Meral Kayıkçıoğlu (D) Serdar Payzın (D)
}

Ege University Medical School Department of Cardiology, Izmir, Turkey

\begin{abstract}
Aim: Treatment methods decreasing mortality in heart failure (HF) are provided in detail by updated guidelines. We aimed to provide true data in our department about the applicability of guidelines into clinical practice on management of HF patients and their follow-up status.

Materials and Methods: We retrospectively assessed the clinical data of patients hospitalized with HF between 2009 and 2010 in our hospital. All the collected data were used to assess the applicability of guidelines and follow-up status for a 5-year time period. A retrospective assessment was preferred in order to reflect the real clinical practice.

Results: There were 496 patients hospitalized for HF between January 2009 and January 2010. New onset and chronic HF were diagnosed in $24.4 \%$ and $75.6 \%$ respectively. The most common scenario of acute HF was pulmonary oedema (77\%). Ischemic heart disease was the predominant etiology $(49.2 \%)$. The median age of patients was $65.62 \pm 14.48$ and $67.7 \%$ of them were male. HF therapies increased from admission to discharge, but decreased during follow-up. Median length of stay was $11.26 \pm 9.26$ days and in hospital mortality $9.5 \%$. The most common complication was infection (18.2\%). During follow-up, hospitalization rate was $88.2 \%$ and long-term mortality $44.5 \%$.

Conclusion: Patients with HF are far away from the cardiovascular prevention targets. The evidencebased therapy recommended by the guidelines was not sufficiently provided. The high rehospitalization and in hospital mortality rate was linked to high rate of pneumonia.
\end{abstract}

Keywords: heart failure, guideline recommended therapy, tertiary medical center, complications, follow-up.

\section{ÖZ}

Amaç: Güncel tedavi kılavuzlarında kalp yetersizliğinde mortalite azaltan girişim ve tedavi yöntemleri ayrıntılı olarak önerilmektedir. Bir tersiyer merkez olarak, kliniğimizde gerçek klinik pratikte kalp yetersizliğinde tedavi yaklaşımı ve uluslararası kılavuzların önerilerine ne kadar uyulduğu, takip durumu tespit etmeye amaçlanmıştır.

Gereç ve Yöntem: Ege Üniversitesi Tıp Fakültesi (EÜTF) Hastanesi Kardiyoloji Kliniğine, 2009 ile 2010 tarihleri arasında kalp yetersizliği kliniği ile yatırılıp tedavi edilen olguların, klinik verilerinin uluslararası kılavuzlarla uyumunun retrospektif olarak değerlendirilmesi ve 5 yıllık bir sürede takibin araştırılması amaçlanmıştır. Çalışmanın gerçek klinik uygulamayı yansıtmasını sağlamak amacıyla retrospektif kohort yöntemin kullanılması uygun görülmüştür.

Bulgular: Çalışmaya, kalp yetersizliği tanısı ile yatırılarak tedavi edilmiş olan 496 hasta alınmıştır. Yeni kalp yetersizliği tanısı $121(\% 24,4)$ hasta, kronik kalp yetersizliği tanısı $375(\% 75,6)$ hasta alınmıştır. Akut kalp yetersizliği klinik tablosu en çok Akciğer ödemi (\%77) ile başvurmuştur. Kalp yetersizliği etiyolojisi olarak en çok iskemik kalp yetersizliği $(\% 49,2)$ saptanmıştır.

\footnotetext{
Corresponding author: Elton Soydan

Ege University Medical School Department of Cardiology;

Izmir Turkey.

E-mail: eltonsoydan@hotmail.com

Application date: 06.02.2021

Accepted: 15.02.2021
} 
Erkek cinsiyetin dominant $(\% 67,7)$ olduğu bulunmuştur. Yaş ortalaması $65,62 \pm 14,48$ olarak bulunmuştur. Kalp yetersizliğinde kullanılan ilaçların taburculuk gününde kullanımı artsa bile, 5 yıllık

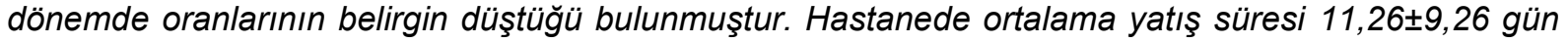
ve mortalite yüksek $(\% 9,5)$ bulunmuştur. En sık komplikasyon enfeksiyon $(\% 18,2)$ olduğu saptanmıştır. Beş yıllık dönemde tekrar hastaneye yatış oranı \%88,2 ve toplam ölüm oranı \%44,5 bulunmuştur.

Sonuç: kalp yetersizliği tanısı alan hastaların kardiyovasküler koruma hedeflerinin gerisinde olduğu, uluslararası kılavuzlarca önerilen kalp yetersizliği tedavilerinin yeterli verilemediği görülmüştür. Takipte de ilaç kullanım oranları belirgin düşmekle beraber en sık tekrardan hastaneye yatış ve mortalite nedeni pnömoni olduğu saptanmıştır.

Anahtar Sözcükler: Kalp yetersizliği, kılavuz önerilen tedavi, tersiyer merkez, komplikasyonlar, takip.

\section{INTRODUCTION}

Heart failure (HF) nowadays has become a high mortality syndrome in developed countries. It is defined as a complex disease resulting from any structural or functional cardiac cause that compromises the diastolic and systolic functions of the left ventricle (1). Occlusion of the coronary arteries by atherosclerotic plaques is the most common structural cause of HF. Other causes could be high blood pressure leading to diastolic dysfunction, valvular diseases, and arrhythmias (2). Progression of HF is linked to left ventricular remodeling process leading to changes in the left ventricle. Many drugs have been discovered to slow the progression of HF and even recover the myocytes from the remodeling process (3). Despite that, variability of presenting symptoms makes the diagnosis difficult and treatment incomplete. As a result, prognosis can be worsened, and hospitalization rate can increase. Applying to international HF guidelines recommendations could prevent mortality and other concomitant diseases and as a result increase survival.

In this study we aimed to examine the characteristics of patients hospitalized with HF, their risk factors, concomitant diseases, and compliance of treatment modalities with the international guidelines in a tertiary medical center and as well, their overall effect on a fiveyear period prognosis. We aimed to get the most real clinical approach, free of other interactions influencing treatment strategies and thus bringing out an indeed meaningful and pure daily practice of HF management on a long-time follow-up period.

\section{MATERIALS and METHODS}

We designed a retrospective cohort study, in which all patients hospitalized with HF between January 2009 and 2010 in our hospital were retrospectively scanned by electronic recording data system. All the collected data were analyzed. According to ICD-10 code, all the patients with an ICD I-50 (HF) were included in the study. HF diagnosis was verified according to actual European Society of Cardiology HF guideline criteria (1). Furthermore, acute HF was classified as pulmonary edema, acute decompensated $\mathrm{HF}$, right ventricular $\mathrm{HF}$, acute coronary syndrome induced HF and cardiogenic shock $(1,4)$. Patients with no previous history of HF were diagnosed with New-onset HF. Instead, acute decompensated chronic HF (ADCHF) was diagnosed in those patients with a previous history of it.

Within this period, we found 788 patients hospitalized with HF. Patients hospitalized more than once, were evaluated in their first admission and the subsequent admissions were considered as a follow-up data. Thirty-five of them were evaluated as not having had a HF diagnosis in spite of the ICD code I-50 in the recording system. In order to have a more homogenous population these patients were excluded from the study. In conclusion, we had 496 patients included. Demographic characteristics, presenting symptoms and signs, comorbidities, in hospital management and all adverse events occurring during hospitalization were recorded. Follow-up evaluation was performed by scanning all the data from the electronic recording system until 2015 august 26-th. Those who had not sufficient follow-up data were called by phone and queried about drugs that had been used, other diseases, hospitalization and even death. The study was designed in accordance with the principles of the declaration of Helsinki. It received approval from the local institutional ethics committee (12-7/16).

\section{Statistical analysis}

Statistical analysis was performed by using SPSS 15.0 program. The suitability of normal distribution of numerical variables were analyzed by Shapiro-Wilk $(\mathrm{n}<50) \quad$ KolmogorvSmirnov $(n>=50)$ test. Numerical variables were shown as mean \pm standard deviation with minimal 
and maximal ranges. Categorical variables were shown as numbers and percentage. Independent two sample $T$ test and Mann-Whitney $U$ test was used according to suitability of normal distribution data. Chi square test was used for categorical variables. Logistic regression analysis was used for assessing risk factors predictive for mortality in different time frames (in-hospital and during follow-up). Drug regimen variability was assessed by using Cochran's $Q$ test. The significance level ( $p$ value) was accepted as $<0.05$ for all hypotheses.

\section{RESULTS}

\section{Demographic characteristics}

Demographic characteristics are shown in Table1. Study population was found as relatively old with a mean age of $65.62 \pm 14.48$ years. Male dominance $(67.7 \%)$ was another distinguishing feature accounting for a significantly higher overweight range of body mass index (28.15 \pm 5.16 vs $27.17 \pm 6.51 \mathrm{p}=0.021)$. Chronic HF was diagnosed in 375 patients $(75.6 \%)$ and almost one third was diagnosed with new onset HF (121: 24.4\%).

Table-1. Clinical characteristics of study population.

\begin{tabular}{|c|c|c|c|c|}
\hline Continous variables & $\begin{array}{c}\text { Total } \\
\text { Mean } \pm \text { SS }\end{array}$ & $\begin{array}{c}\text { Male } \\
\mathrm{N}: 336\end{array}$ & $\begin{array}{l}\text { Female } \\
\mathrm{N}=160\end{array}$ & $P$ value \\
\hline Age & $65.62 \pm 14.48$ & $65.21 \pm 14.48$ & $66.37 \pm 14.48$ & 0.287 \\
\hline Length (meters) & $16.5 \pm 0.05$ & $1.65 \pm 0.05$ & $1.63 \pm 0.048$ & 0.001 \\
\hline Weight & $75.7 \pm 14.7$ & $77.18 \pm 13.69$ & $72.60 \pm 16.23$ & 0.001 \\
\hline BMI & $27.83 \pm 14.7$ & $28.15 \pm 5.16$ & $27.17 \pm 6.51$ & 0.021 \\
\hline Hospital stays (day) & $11.26 \pm 9.26$ & $10.95 \pm 9.11$ & $11.91 \pm 9.56$ & 0.236 \\
\hline Systolic (mmHg) & $131.37 \pm 23.63$ & $130.14 \pm 22.38$ & $134.14 \pm 25.83$ & 0.094 \\
\hline Diastolic (mmHg) & $78.36 \pm 14.18$ & $77.8 \pm 13.85$ & $79.57 \pm 14.81$ & 0.297 \\
\hline Heart rate (minutes) & $91.30 \pm 27.52$ & $91.46 \pm 27.23$ & $90.96 \pm 28.20$ & 0.972 \\
\hline Presentation features & $\begin{array}{l}\text { Total } \\
\text { N (\%) }\end{array}$ & Male & Female & $P$ value \\
\hline Dyspnea & $416(84)$ & $276(82.4)$ & $140(87.5)$ & 0.146 \\
\hline Pretibial edema & 237 (47.9) & $155(46.3)$ & $82(51.2)$ & 0.299 \\
\hline Angina & $68(13.7)$ & $50(14.9)$ & $18(11.3)$ & 0.267 \\
\hline Asymptomatic & $37(7.5)$ & $27(8.1)$ & $10(6.3)$ & 0.474 \\
\hline Ascites & $23(4.6)$ & $16(4.8)$ & $7(4.4)$ & 0.843 \\
\hline Syncope & $9(1.8)$ & $6(1.8)$ & $3(1.9)$ & 0.948 \\
\hline Cardiac Arrest & $3(0.6)$ & $2(0.6)$ & $1(0.6)$ & 1.000 \\
\hline Concomitant diseases & $\begin{array}{l}\text { Total } \\
\text { N (\%) }\end{array}$ & \multicolumn{2}{|c|}{ N (\%) } & $P$ value \\
\hline HT & $287(58)$ & $188(56.1)$ & $99(61.9)$ & 0.225 \\
\hline CAD & $229(46.3)$ & $176(52.5)$ & $53(33.1)$ & 0.000 \\
\hline Smoking & $227(45.9)$ & $201(60)$ & $26(16.3)$ & 0.000 \\
\hline DM & $162(32.7)$ & $98(29.3)$ & $64(40)$ & 0.017 \\
\hline Obesity & $144(29.1)$ & $87(26)$ & $57(35.6)$ & 0.027 \\
\hline HLP & $135(27.3)$ & $92(27.5)$ & $43(26.9)$ & 0.891 \\
\hline COPD & $112(22.6)$ & $86(25.7)$ & $26(16.3)$ & 0.019 \\
\hline $\mathrm{AF}$ & $105(21.2)$ & $69(20.6)$ & $36(22.5)$ & 0.626 \\
\hline CABG & $90(18.2)$ & $72(21.5)$ & $18(11.3)$ & 0.006 \\
\hline ICD & $28(5.7)$ & $23(6.9)$ & $5(3.1)$ & 0.092 \\
\hline
\end{tabular}

AF: Atrial Fibrillation; COPD: Chronic Obstructive Pulmonary Disease; CABG: Coronary Artery Bypass Grafting; CAD: Coronary Artery Disease; CKD: Chronic Kidney Disease; DM: Diabetes Mellitus; HT: Hypertension; HLP: Hyperlipidemia; ICD: Intracardiac Defibrillator. 
Acute HF presentation rate was significantly higher in the chronic group (347 vs 112 patients $\mathrm{p}<0.001$ ) (Figure-1). Acute pulmonary edema was found as the most emerging clinical scenario of acute HF $(P<0.001) \quad$ (Figure-2). This presentation was found higher in male gender in both new onset and chronic HF although not reaching a significant level ( $p>0.05)$ (Figure-3, 4). The other accompanying scenarios were acute decompensated $\mathrm{HF}$, right ventricle HF, acute coronary syndrome induced HF and cardiogenic shock.

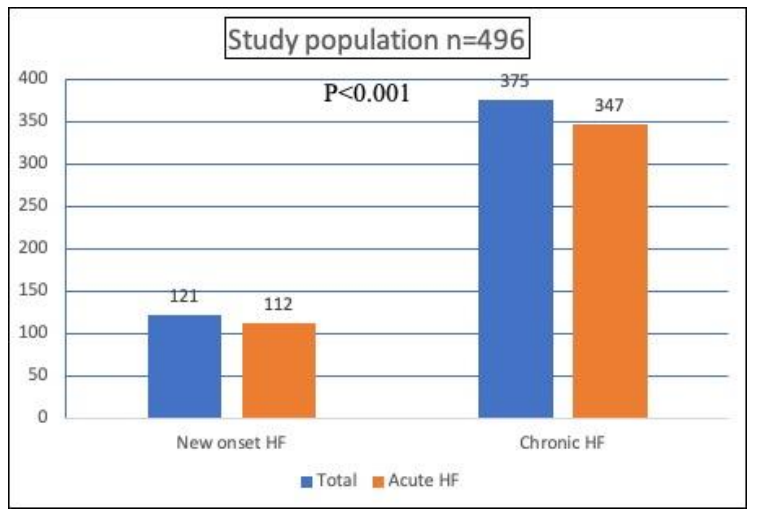

Figure-1. New onset and chronic heart failure distribution in the study population.

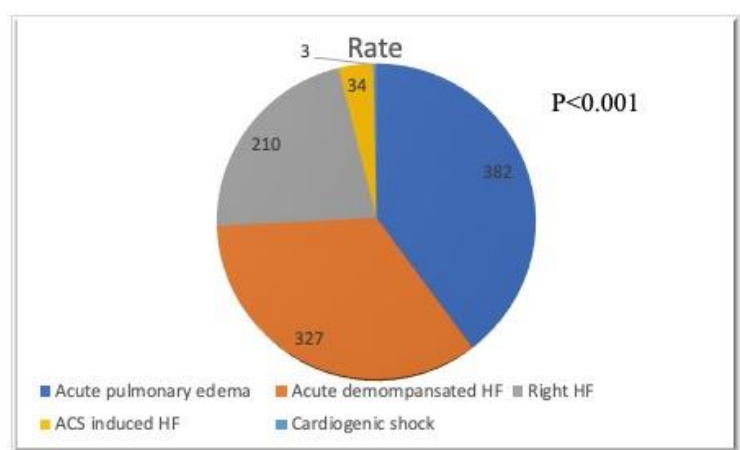

Figure-2. Constellation of clinical scenarios in acute HF.

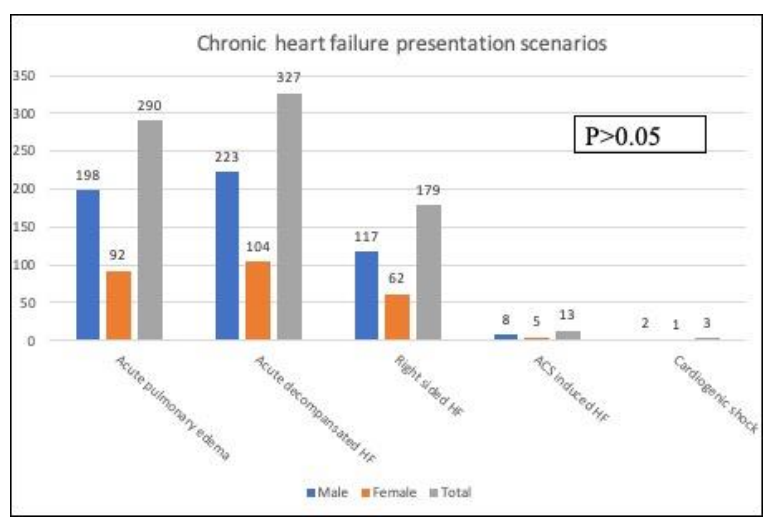

Figure-3. Clinical scenarios in acute presentation of new onset heart failure.

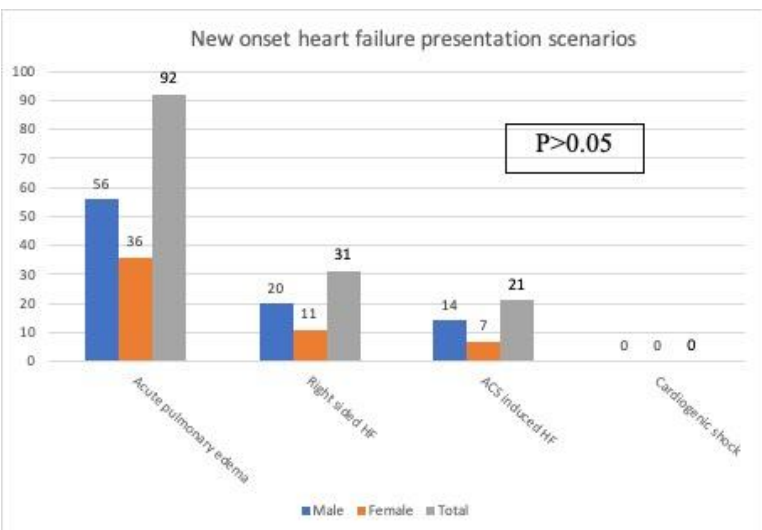

Figure-4. Clinical scenarios in acute presentation of chronic heart failure.

\section{Presenting characteristics}

The most common presenting symptom was dyspnea (84\%). Pretibial edema and ascites were the subsequent presenting findings with rates of $47.9 \%$ and $4.6 \%$ respectively. Interestingly, 37 patients diagnosed with HF were asymptomatic on admission. Three patients presented with cardiac arrest. Patients admitted had a mean systolic and diastolic blood pressure in a high-normal range as: $131.28 \pm 2$ and $78.3 \pm 14.34 \mathrm{mmHg}$ respectively. A relatively long hospital stay (11.26 \pm 9.26 days) implied challenge in the management of HF patients. Although a higher trend in women, no statistical difference was found in presenting features.

\section{Cardiovascular risk factors and concomitant diseases}

The most common cardiovascular risk factor was hypertension (58\%). Coronary artery disease (CAD) and smoking showed a significantly higher burden in male gender $(<0.001)$. However, Diabetes Mellitus was interestingly found higher in women $(p=0.017)$. Hyperlipidemia (HLP) was found similar in both genders $(p=0.626)$.

\section{Etiology of heart failure}

As it might be assumed, ischemic cause was the most common HF etiology with a rate of $49.2 \%$. Idiopathic (non-ischemic) cardiomyopathy was found in $35.1 \%$. In addition, valvular causes had a rate of $11.9 \%$. Preserved ejection fraction (EF) HF defined as left ventricular EF of $>50 \%$, had a rate of $1.8 \%$. Tachycardia induced HF was diagnosed in 5 patients $(1 \%)$, hypertrophic cardiomyopathy in $3(0.6 \%)$ and restrictive cardiomyopathy only in 2 patients $(0.4 \%)$ (Figure-5). 


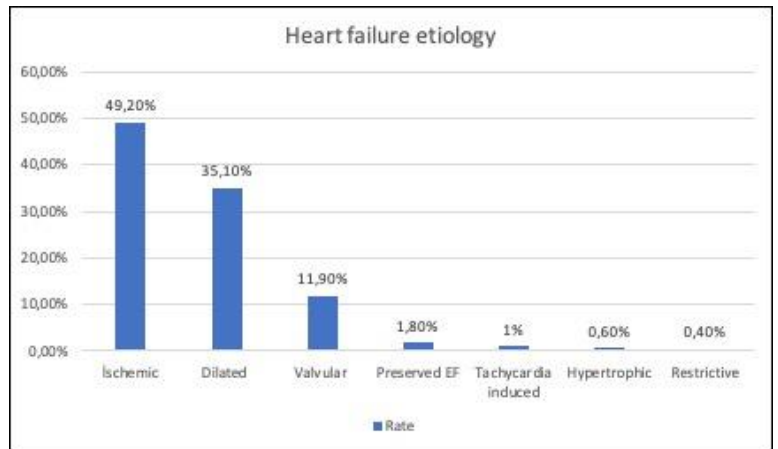

Figure-5. Etiology in heart failure.

\section{Drug use before hospitalization}

Drug use rate before hospitalization is depicted in Table-2. There was a low rate of guideline recommended drug use in HF patients. Aspirin and furosemide were the most common used drugs $(48.3 \%$ and $49.3 \%$ respectively). Beta blockers and angiotensin converting enzyme inhibitors (ACE-inh.) were the subsequent drugs used in $46.5 \%$ and $32.8 \%$ respectively. However, no statistical difference was seen between genders except for spironolactone being used in a higher rate in male patients $(p=0.016)$. Statin use as well, were found higher in male patients but with no statistical difference $(p=0.588)$. Interestingly, angiotensin receptor blocker (ARB) use showed the lowest rate (13.5\%) among other prescribed drugs.

\section{Electrocardiography and echocardiography findings}

Electrocardiographic and echocardiographic features are shown in Table-3. Sinus rhythm was the most prominent rhythm seen in electrocardiography (ECG) on admission. It was followed by atrial fibrillation (AF) (37\%). Patients presenting with ventricular tachycardia mostly $(83.3 \%)$ had an ischemic etiology. Arrhythmias occurring during hospitalization were detected in 46 patients $(9.2 \%)$. The most frequent arrhythmia was ventricular tachycardia in $4.2 \%$. The second most common one was ventricular fibrillation and new onset AF (2.4\%). In contrast to similar findings of electrocardiographic data, male patients showed a significantly lower left and right ventricle EF $(33.86 \pm 13.80$ vs $39.24 \pm 14.35$ $p<0.001 ; 49.22 \pm 12.25$ vs $52.30 \pm 10.22 p=0.016$ respectively). Mitral and tricuspid valvular regurgitation were the most emerging valvular pathologies similarly seen in both genders $(p=0.206$ and $p=0.547$ respectively).

\section{Laboratory findings during hospitalization}

Laboratory findings are shown in Table-4. NT-Pro Brain Natriuretic Peptide considered a good biomarker in HF severity was found increased on admission. Although higher in male patients, there were no statistical significance between genders $(p=0.885)$. Creatinine level was higher in male gender, thought to be due to furosemide use and higher body muscle mass ( $p=0.027)$. Female patients were found to be anemic with a significantly lower hemoglobin $(\mathrm{Hb})$ level (11.84 $\pm 1.95 \mathrm{~g} / \mathrm{dl}: \mathrm{p}=0.001)$.

In contrast to high rates of CAD, low density lipoprotein (LDL) mean value was found in a low range as $98.63 \pm 36.96 \mathrm{mg} / \mathrm{dL}$, showing similarity between genders $(p=0.608)$. It was thought to be due to higher previous statin use.

Table-2. Drug use before hospitalization.

\begin{tabular}{lcccc}
\hline Drug & $\begin{array}{c}\text { Total } \\
\text { N (\%) }\end{array}$ & $\begin{array}{c}\text { Male } \\
\text { N (\%) }\end{array}$ & $\begin{array}{c}\text { Female } \\
\text { N (\%) }\end{array}$ & P value \\
\hline Aspirin & $239(48.3)$ & $180(53.7)$ & $76(47.5)$ & 0.194 \\
Furosemide & $244(49.3)$ & $166(49.6)$ & $78(48.8)$ & 0.867 \\
Beta blocker & $231(46.5)$ & $157(46.8)$ & $74(46.3)$ & 0.736 \\
ACE-inh & $163(32.9)$ & $116(34.4)$ & $47(29.5)$ & 0.493 \\
Spironolactone & $150(30.3)$ & $113(33.7)$ & $37(23.1)$ & 0.016 \\
Hydrochlorothiazide & $126(25.5)$ & $82(24.5)$ & $44(27.5)$ & 0.470 \\
Digoxin & $123(24.8)$ & $87(26)$ & $36(22.5)$ & 0.403 \\
Warfarin & $104(21)$ & $74(22.1)$ & $30(18.8)$ & 0.394 \\
Statin & $85(17.2)$ & $60(17.8)$ & $25(15.6)$ & 0.588 \\
ARB & $67(13.5)$ & $41(12.3)$ & $26(32.6)$ & 0.090 \\
\hline
\end{tabular}

ACE: Angiotensin Converting Enzyme; ARB: Angiotensin Receptor Blocker. 
Table-3. Electrocardiographic and echocardiographic findings.

\begin{tabular}{ccccc}
\hline Rhythm & $\begin{array}{c}\text { Total } \\
\mathbf{N}(\%)\end{array}$ & $\begin{array}{c}\text { Male } \\
\mathbf{N}(\%)\end{array}$ & $\begin{array}{c}\text { Female } \\
\mathbf{N}(\%)\end{array}$ & P value \\
\hline Sinus rhythm & $276(55.8)$ & $188(56.6)$ & $88(55.7)$ & \\
AF & $183(37)$ & $121(36.4)$ & $62(39.2)$ & 0.774 \\
Pace Rhythm & $25(5.1)$ & $18(5.4)$ & $7(4.4)$ & \\
VT & $6(1.2)$ & $5(1.5)$ & $1(0.6)$ & \\
Arrhythmia during hospitalization & $21(4.2)$ & $13(3.9)$ & $8(5)$ & 0.563 \\
VT & $4(0.8)$ & $3(0.9)$ & $1(0.6)$ & 0.753 \\
New AF & $16(3.2)$ & $12(3.6)$ & $4(2.5)$ & 0.524 \\
VF & $5(1)$ & $3(0.9)$ & $2(1.3)$ & 0.326 \\
Total AV block & & & & \\
Echocardiography findings & & & & \\
Feature & $35.6 \pm 14.19$ & $33.86 \pm 13.80$ & $39.24 \pm 14.35$ & 0.001 \\
LVEF (\%) & $50.21 \pm 11.71$ & $49.22 \pm 12.25$ & $52.30 \pm 10.22$ & \\
RVEF (\%) & & & & 0.016 \\
Valvular pathologies & $461(93.1)$ & $315(94.1)$ & $146(91.2)$ & 0.547 \\
MR & $436(88)$ & $295(88.1)$ & $141(88.1)$ & \\
TR & & & & \\
\hline
\end{tabular}

MR: Mitral regurgitation; TR: Tricuspid regurgitation; AR: aortic regurgitation: LA: Left atrium; LVEDD: Left ventricle end diastole dimension; LVESD. Left ventricle end systole dimension LVEF: Left ventricle ejection fraction; RVEF: Right ventricle ejection fraction; SPAP: Systolic pulmonary arterial pressure; SD: Standard deviation.

Table-4. Biochemical tests during hospitalization.

\begin{tabular}{ccccc}
\hline Laboratory & $\begin{array}{c}\text { Total } \\
\text { Mean } \pm \text { SS }\end{array}$ & $\begin{array}{c}\text { Male } \\
\text { Mean } \pm \text { SS }\end{array}$ & $\begin{array}{c}\text { Female } \\
\text { Mean } \pm \text { SS }\end{array}$ & P value \\
\hline NT Pro BNP $(\mathrm{pg} / \mathrm{ml})$ & $11166.33 \pm 16173.80$ & $13232.89 \pm 20232.89$ & $8284.04 \pm 6806.16$ & 0.885 \\
Troponin $(\mathrm{ng} / \mathrm{ml})$ & $0.329 \pm 1.09$ & $0.36 \pm 1.16$ & $0.25 \pm 0.61$ & 0.308 \\
Creatinine $(\mathrm{mg} / \mathrm{dl})$ & $1.33 \pm 0.69$ & $1.4 \pm 0.73$ & $1.16 \pm 055$ & $<0.001$ \\
NA $(\mathrm{mmol} / \mathrm{L})$ & $138.36 \pm 5.84$ & $138.07 \pm 5.43$ & $138.93 \pm 6.58$ & 0.027 \\
K (mmol/L) & $4.47 \pm 0.66$ & $4.50 \pm 0.68$ & $4.42 \pm 0.61$ & 0.644 \\
Hemoglobin $(\mathrm{g} / \mathrm{dl})$ & $12.32 \pm 2.15$ & $12.55 \pm 2.21$ & $11.84 \pm 1.95$ & 0.001 \\
Cholesterol & $160.80 \pm 47.44$ & $157.93 \pm 47.66$ & $166.76 \pm 46.58$ & 0.116 \\
LDL $(\mathrm{mg} / \mathrm{dL})$ & $98.63 \pm 36.96$ & $97.57 \pm 36.62$ & $100.83 \pm 37.72$ & 0.608 \\
CRP $(\mathrm{mg} / \mathrm{dl})$ & $4.44 \pm 5.23$ & $4.35 \pm 4.81$ & $4.61 \pm 6.10$ & 0.797 \\
\hline
\end{tabular}

NT pro BNP: NT pro Brain natriuretic Peptide CK: Creatin Kinase; NA: Sodium; K: Potassium; LDL: Low Density Lipoprotein; TG: Triglyceride; HDL: High Density Lipoprotein HBA1c: Hemoglobin A1C; CRP: C- reactive protein; INR: International Normalized ratio; SD: Standard deviation.

\section{Administration of drugs during hospitalization}

Administration rates of HF treatment is shown in Figure-6. According to their preadmission rate, we saw an increase in the rate of beta blockers,
ACE-inh. and aldosterone antagonists. Beta blockers had the highest increase rate $(61.2 \%)$. ARB drugs were slightly decreased according to their preadmission rate. 


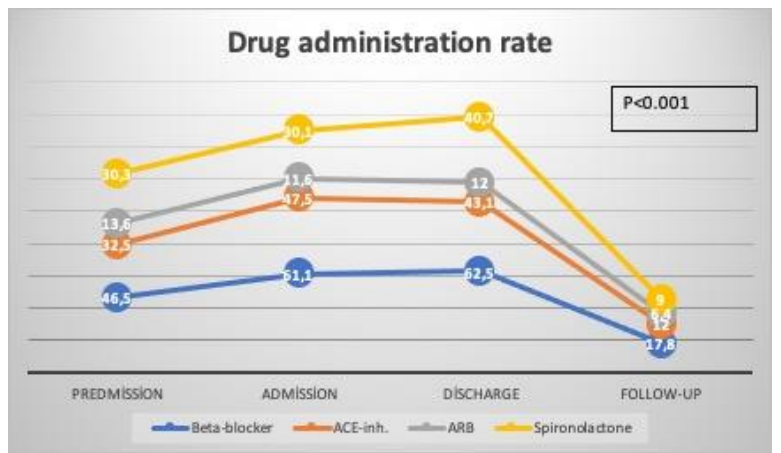

Figure-6. Drug administration rate on preadmission, hospitalization, discharge and follow-up period.

\section{In hospital mortality and complications}

In-hospital mortality causes are depicted in Table-5. There was a relatively high rate of inhospital mortality $(9.6 \%)$ of the study population. The most common one was pneumonia as an infection disease emerging in $18.2 \%$ of all patients. Multivariate logistic regression of inhospital mortality showed that gender was not predictive for mortality. In contrast to age, decreasing of BMI was shown positively predictive for in-hospital mortality (odds ratio: $0.942 \mathrm{p}=0.047$ ), highlighting the importance of cardiac cachexia, a very dangerous lifethreatening syndrome. In addition, presenting symptoms were not predictive except for syncope, being the result of serious arrhythmias (ventricular tachycardia) during admission. Considering acute heart failure scenarios, only ACS induced heart failure was shown to be predictive of in-hospital mortality. It was thought to be due to higher KILLIP class (class III) in almost all patients admitted with that diagnosis. There was no significant difference in complications occurring between new onset and chronic HF. Astonishingly, these complications were found to be strongly predictive to mortality. Among them, pneumonia was one of the main precipitating factors to decompensation of $\mathrm{HF}$ patients.

\section{Follow-up findings}

Follow-up findings are shown in Table-6. Controlvisit was performed to 406 patients (81.9\%) from 451 patients discharged from the hospital. Fortythree patients $(8.6 \%)$ had no hospital follow-up recordings and could not be reached by phone or other telecommunicating tools and it was found that they lived abroad, with no possibility to have their follow-up in our hospital. Rehospitalization rate was found as $88.2 \%$ at 5 -year follow-up and showed no difference between genders $(p=0.413)$. The most common cause of rehospitalization was decompensation of $\mathrm{HF}$ $(70.7 \%)$. Interestingly, pneumonia rate was found to be increased from $18.2 \%$ to $23.2 \%$, being one of the causes of decompensation leading to rehospitalization. At 5-year follow-up, study population showed a highly increased mortality rate of $44.5 \%$. Pneumonia showed a steadily high rate $(17.7 \%)$ of mortality in decompensated $\mathrm{HF}$ patients.

There was a sustained increase in the rate of main HF drugs such as beta-blockers, ACE-inh., ARB and spironolactone during hospitalization period. At discharge, administration rates were significantly increased in beta blockers, ACE-inh. and spironolactone $(p<0.001)$. In contrast, ARB drugs didn't catch a significant increase at discharge day, thought to be due to ACE-inh. preference. At 5-year follow-up instead, a significant decrease in all of the aforementioned drugs was found $(p<0.001)$.

Table-5. Causes of in-hospital mortality.

\begin{tabular}{ccccc}
\hline & Total & Male & Female & P value \\
\hline Mortality & $47(9.5)$ & $32(9.6)$ & $15(9.4)$ & 0.95 \\
Infection & $90(18.2)$ & $61(18.2)$ & $29(18.1)$ & 0.982 \\
Arrhythmia & $33(6.7)$ & $23(6.9)$ & $10(6.3)$ & 0.854 \\
Cardiac arrest & $52(10.5)$ & $35(10.4)$ & $17(10.6)$ & 0.952 \\
Acute kidney failure & $39(7.9)$ & $26(7.8)$ & $13(8.1)$ & 0.888 \\
Cardiogenic Shock & $33(6.7)$ & $22(6.6)$ & $11(6.9)$ & 0.898 \\
Bleeding & $19(3.8)$ & $13(3.9)$ & $6(3.8)$ & 0.944 \\
Pulmonary emboli & $2(0.4)$ & $1(0.3)$ & $1(0.6)$ & 0.542 \\
\hline
\end{tabular}


Table-6. Findings at 5 year-follow-up.

\begin{tabular}{|c|c|c|c|c|}
\hline Findings & $\begin{array}{l}\text { Total } \\
\text { N (\%) }\end{array}$ & $\begin{array}{l}\text { Male } \\
\text { N (\%) }\end{array}$ & $\begin{array}{c}\text { Female } \\
\text { N (\%) }\end{array}$ & $P$ value \\
\hline Total follow-up control & $406(81.9)$ & $275(55.4)$ & $131(26.5)$ & \\
\hline No follow-up & $43(8.6)$ & $29(5.8)$ & $14(2.8)$ & 0.969 \\
\hline Rehospitalization & $358(88.2)$ & $240(59.1)$ & $118(29.1)$ & 0.838 \\
\hline \multicolumn{5}{|c|}{ Causes of rehospitalization during follow-up N=358 (\%) } \\
\hline Heart failure progression & $253(70.7)$ & $169(47.2)$ & $84(23.5)$ & 0.504 \\
\hline Arrhythmia & $71(19.9)$ & $51(14.3)$ & $20(5.6)$ & 0.416 \\
\hline Infection & $86(24)$ & 59 (16.5) & $27(7.5)$ & 0.846 \\
\hline Pneumonia & $83(23.2)$ & $57(15.9)$ & $26(7.3)$ & \\
\hline Acute coronary syndrome & $38(10.6)$ & $25(7)$ & $13(3.6)$ & 0.788 \\
\hline \multicolumn{5}{|c|}{ Mortality rate during follow-up N=406 (\%) } \\
\hline Mortality & $181(44.5)$ & $127(31.2)$ & 54 (13.3) & 0.473 \\
\hline $\begin{array}{l}\text { Mortality causes during } \\
\text { follow-up }\end{array}$ & $\begin{array}{l}\text { Total } \\
\mathbf{N}(\%)\end{array}$ & $\begin{array}{c}\text { Male } \\
\mathrm{N}(\%)\end{array}$ & $\begin{array}{l}\text { Female } \\
\mathrm{N}(\%)\end{array}$ & $P$ value \\
\hline Progression of heart failure & $152(37.4)$ & $107(26.3)$ & $45(11.1)$ & 0.964 \\
\hline Pneumonia & $72(17.7)$ & $54(13.3)$ & $18(4.4)$ & 0.442 \\
\hline MI & $7(1.7)$ & $6(1.4)$ & $1(0.3)$ & 0.375 \\
\hline Malignity & $23(5.6)$ & $17(4.2)$ & $6(1.4)$ & 0.710 \\
\hline
\end{tabular}

\section{DISCUSSION}

In this study we found that the most common presenting scenario in new onset acute HF was hypertensive pulmonary edema. However, the mean systolic blood pressure during admission was $131.37 \mathrm{mmHg}$ and it was found that the first intervention was done in the emergency room and thus lowered the systolic blood pressure during admission to our clinic. As we have a look at the Euro Heart Failure Survey II (EFS II) study we see that the most triggering factor of new onset acute HF is acute coronary syndrome (4). However, in our study this attributed to only $18.7 \%$ of new onset acute HF.

The collected data showed that the high rate of hypertensive pulmonary edema both in the new onset acute HF and chronic decompensated HF group could be attributed to ineffective or deficient treatment of hypertension before admission, being similar to both genders. ADHERE study had a similar rate of new onset acute HF (24\%) with our data (5).

The mean age of patients included in our study is $65.62 \pm 14.5$ years. Our population is found to be younger than other international studies (6). Male predominance $(67.7 \%)$ shows a similar and even a higher rate than EFSII, ATTEND, BADAPIC study $(4,6,7)$. Unlike these studies, evaluation of both new onset acute and chronic HF in the study could have attributed to the higher male predominance. The cause of both new onset and chronic HF was ischemic heart disease with rates of $48.3 \%$ and $49.2 \%$ respectively. Male gender predominance in our study reminds us of the importance of it as a risk factor for ischemic heart disease and eventually HF.

Tokgözoğlu et al. found that Turkish people had $C A D$ in a younger age compared to Europeans. Also, smoking habit after MI, immobility, and low levels of high-density lipoprotein rates were higher in Turkish people (8). Accordingly, the risk factors mentioned in the EUROASPIRE study highlights the cause of the younger population in our study. Classification of presenting symptoms shows similarity with the literature. Dyspnea was the most common presenting symptom in our HF patients (84\%). Other cardiovascular risk factors such as HT, CAD, DM, were found similar with EFSII study (4). Actually, the high rate of these risk factors is an expected condition as the EUROASPIREIII study showed that the treatment goals described in the prevention guidelines for patients with CAD were not achieved at all (8). 
Another important cardiovascular risk factor is HLP found in $27.3 \%$ in our study. ROMANIAN, AHF, EFICA, and OPTIMIZE HF studies had a higher HLP rate $(9,10,11)$. HLP rate in Turkey according to the EURIKA study was found $34.5 \%$ lower than the mean European rate (57.7\%) (12). Although our HLP rate is supported from the EURIKA study, levels of LDL were measured as $99 \pm 37 \mathrm{mg} / \mathrm{dl}$ being similar in both genders. It was thought that the cause of low lipid levels was related to statin use before admission. However, statin rate before admission was only $17.2 \%$. In fact, HF progression is a chronic inflammatory syndrome, that can lead to malnutrition and cachexia, an important factor accounting to low lipid levels (13).

Retrospective studies have shown that anemia is correlated with mortality and morbidity in HF patients (14). Diagnostic criteria of anemia according to World Health Organization (WHO) are defined as for men and women: hemoglobin $(\mathrm{Hb})<13 \mathrm{~g} / \mathrm{dl}$ and $\mathrm{Hb}<12 \mathrm{~g} / \mathrm{dl}$ respectively (15). In our study $\mathrm{Hb}$ mean value was $12.32 \mathrm{~g} / \mathrm{dl}$. Anemia was diagnosed both in men and women. One of the causes of anemia could be the hematologic toxic effects of the use of antithrombotic drugs, ACE-inh., anti-arrhythmic drugs and other antihypertensive drugs.

Mean value of left ventricle EF of the study was found as $35.6 \pm 14.19 \%$. Although there was not an advanced left ventricle systolic dysfunction, our in-hospital mortality was found as $9.5 \%$, a rate higher than other similar studies $(4,5)$. Infection, especially pneumonia was found to be the most common complication during hospital stay $(18.2 \%)$. In relation to these features mean hospital stay was (11.26 days) longer than other international studies (4). This difference was thought to be due to the high frequency of infection diseases. Patients with HF carry high risk for developing pneumonia in a nosocomial environment. Studies have shown that vaccination from the Influenza virus and Pneumococcus could markedly decrease cardiovascular mortality and hospitalization (1617). Relevantly we found no patient entering a vaccination program during hospital stay and follow-up period, and this feature implies a big deficiency in the comprehensive management of $\mathrm{HF}$ patients in a tertiary medical center.

Although international HF guidelines recommend the use of beta blockers, ACE-inh or ARB in all patients with chronic $\mathrm{HF}$, use of these drugs before admission was astonishingly low as $46.1 \%, 32.5 \%$ and $13.6 \%$ respectively (1). One of the possible low rates of beta blockers could be chronic obstructive pulmonary disease (COPD) leading to ensuing bronchospasm. However only bronchial asthma is a contraindication for beta blockers, and they can be easily used in COPD. This has been supported by protective cardiac and non-cardiac potential features of beta blockers preventing remodulation of the left ventricle and reducing pro-inflammatory cytokines exacerbating COPD (17).

After discharge hospital recording rate of followup of patients was found to be high as $81.9 \%$. Unfortunately use of beta blockers, ACE-inh, ARB and spironolactone was low again as $17.8 \%, 12 \%, 6.4 \%$ and $9 \%$ respectively. Rehospitalization rate during a 5-year period was $88.2 \%$. High rate of rehospitalization and 5-year mortality $(44.5 \%)$ reflected insufficient use of medications recommended by international HF guidelines and as well, underscores the urgent enrollment of these patients to lifesaving vaccination program.

\section{Study limitations}

Retrospective design of this study represents a limitation based on evaluation of only clinical data recorded on patient electronic files. Accurate documentation cannot be expected and other not recorded findings could have influenced our results. However, follow-up findings reached by recorded electronic data and affirmed by telephone as well, can be excepted as valuable data having a strong impact on management of HF patients in a tertiary medical center. A major value of this study was its 'real life' evaluation of HF patients according to gender during hospitalization and follow-up. Prospective large sample population studies are needed to accurately clarify the causes of change in guideline recommended management.

\section{CONCLUSION}

Our study showed the real clinical approach to HF patients admitted to a tertiary medical center and the real 5-year follow-up data. This study brought up the following conclusions:

1) Patients with HF were far away from cardiovascular prevention targets before admission.

2) Our in-hospital mortality was higher than other studies, unfortunately linked to infection diseases. 
3) There is a big challenge of efficiently providing evidence-based therapy during follow-up.

4) Follow-up showed high rehospitalization rate due to again infection diseases, especially pneumonia, a feature that should urgently emphasize the protective value of vaccination in these group of patients.

\section{Conflict of interest}

The authors declare no conflict of interest.

\section{Funding Sources}

This study is not funded by any source.

\section{References}

1. Ponikowski P, Voors AA, Anker SD, et al. ESC Scientific Document Group. 2016 ESC Guidelines for the diagnosis and treatment of acute and chronic heart failure: The Task Force for the diagnosis and treatment of acute and chronic heart failure of the European Society of Cardiology (ESC) Developed with the special contribution of the Heart Failure Association (HFA) of the ESC. Eur Heart J. 2016 Jul 14; 37 (27): 2129-200.

2. Ziaeian B, Fonarow GC. Epidemiology and aetiology of heart failure. Nat Rev Cardiol. 2016 Jun; 13 (6): $368-78$.

3. Sciatti E, Dallapellegrina L, Metra M, Lombardi CM. New drugs for the treatment of chronic heart failure with a reduced ejection fraction: What the future may hold. J Cardiovasc Med (Hagerstown). 2019 Oct; 20 (10): 650-9.

4. Nieminen MS, Brutsaert D, Dickstein K, et al. EuroHeart Survey Investigators; Heart Failure Association, European Society of Cardiology. EuroHeart Failure Survey II (EHFS II): a survey on hospitalized acute heart failure patients: description of population. Eur Heart J. 2006 Nov; 27 (22): 2725-36.

5. Adams Jr KF, Fonarow GC, Emerman CL, et al. Characteristics and outcomes of patients hospitalized for heart failure in the United States: rationale, design, and preliminary observations from the first 100,000 cases in the Acute Decompensated Heart Failure National Registry (ADHERE). Am Heart J 2005; 149: 209-16.

6. Sato N, Kajimoto K, Asai K. Et al. Acute decompensated heart failure syndromes (ATTEND) registry. A prospective observational multicenter cohort study: Rationale, design, and preliminary data Am Heart J 2010; 159: 949-55.

7. Anguita Sánchez M; Clinical Characteristics, Treatment and Short-Term Morbidity and Mortality of Patients With Heart Failure Followed in Heart Failure Clinics. Results of the BADAPIC Registry Rev Esp Cardiol 2004; 57 (12): 1159.

8. Lale Tokgözoğlu, Ergün Barış Kaya, Çetin Erol, et al. EUROASPIRE III: a comparison between Turkey and EuropeTürk Kardiyol Dern Arş - Arch Turk Soc Cardiol 2010; 38 (3): 164-72.

9. Ovidiu Chioncel, Dragos Vinereanu. The Romanian Acute Heart Failure Syndromes (RO-AHFS) RegistryAm Heart J 2011; 162: 142-53.

10. Zannad F, Mebazaa A, Juilliere $Y$, et al. Clinical profile, contemporary management and one-year mortality in patients with severe acute heart failure syndromes: the EFICA study. Eur J Heart Fail 2006; 8:697-705.

11. Abraham WT, Fonarow GC, Albert NM, et al. Predictors of inhospitalmortality in patients hospitalized for heart failure: insights from the Organized Program to Initiate Lifesaving Treatment in Hospitalized Patients With Heart Failure (OPTIMIZE-HF). J Am Coll Cardiol 2008; 52: 347-56.

12. Abaci A. Management of cardiovascular risk factors for primary prevention: evaluation of Turkey results of the EURIKA study. Turk Kardiyol Dern Ars. 2012 Mar; 40 (2): 135-42.

13. Fonarow GC, Srikanthan P, Costanzo MR, et al. An obesity paradox in acute heart failure: analysis of body mass index and inhospital mortality for 108927 patients in the Acute Decompensated Heart Failure National Registry. Am Heart J 2007; 153: 74.

14. Felker GM, Adams Jr KF, Gattis WA, et al. Anemia as a risk factor and therapeutic target in heart failure. J Am Coll Cardiol 2004; 44: 959-66.

15. World Health Organization. Iron deficiency anemia, assessment, prevention, and control: report of a WHO Scientific Group. Geneva, Switzerland: World Health Organization; 2001. Available from www.who.int.

16. Wolney de Andrade Martins. Influenza and Pneumococcal Vaccination in Heart Failure - a little Applied Recommendation Arq Bras Cardiol 2011; 96 (3): 240-5.

17. Ankeet S. Bhatt, Adam D. DeVore, Adrian F. Hernandez, et al. Can Vaccinations Improve Heart Failure Outcomes? J Am Coll Cardiol HF. 2017 Mar, 5 (3) 194-203. 